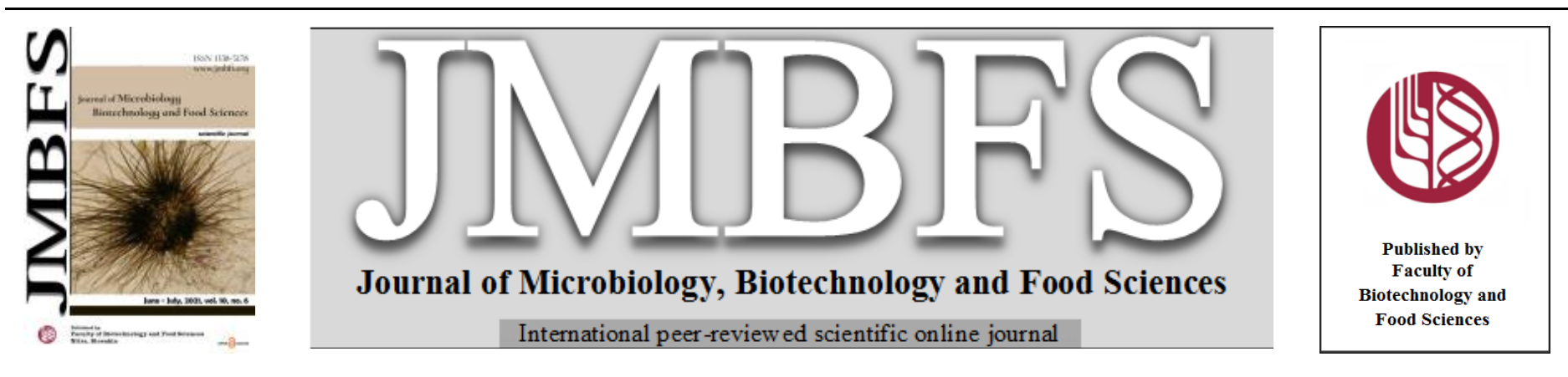

\title{
DEVELOPMENT AND PROCESS OPTIMIZATION OF SPRAY DRIED POWDER FROM ENZYMATICALLY EXTRACTED RIPE PALM (Borassus flabellifer) JUICE
}

\author{
Soberly Mohanty, Sabyasachi Mishra*, Rama Chandra Pradhan
}

Address(es):

Department of Food Process Engineering, National Institute of Technology, Rourkela, Odisha, India, Pin-769008.

*Corresponding author: mishrasa@nitrkl.ac.in

https://doi.org/10.15414/jmbfs.2539

\section{ARTICLE INFO}

Received 13. 1. 2020

Revised 25. 1. 2021

Accepted 2. 2. 2021

Published 1. 6. 2021

Regular article

open $\partial_{\text {access }}$

\begin{abstract}
Ripe Palm (Borassus flabellifer) juice contains high sugars that make it difficult to store for a longer period, which limits its use for spray drying. The present work explores the feasibility and optimization of spray drying to make powder from enzymatically extracted ripe palm juice using maltodextrin and gum Arabic as wall materials. Various parameters such as moisture, water activity, solubility, ascorbic acid, colour change, and yield were optimized using response surface method with the central composite design. A mixture of maltodextrin and gum Arabic at a ratio of $3: 1(\mathrm{w} / \mathrm{w})$ combined with lactose, and spray drying with an inlet temperature of $140^{\circ} \mathrm{C}$ resulted in the optimum powder quantity and quality. The palm powder yield was maximum $(63.5 \pm 0.29 \%)$ with acceptable solubility $(31.6 \pm 0.33$ secs), colour change $(\Delta \mathrm{E}=18.37 \pm 0.03)$, ascorbic acid content $(54 \pm 0.0003 \mu \mathrm{g} / \mathrm{ml})$, moisture content $(3.3 \pm 0.61)$, and water activity $(0.29 \pm 0.05)$. The optimized conditions can be replicated on an industrial scale for the production of palm powder.
\end{abstract}

Keywords: Palm fruit, Fruit juice, Spray drying, Encapsulation, Quality assessment

\section{INTRODUCTION}

Palm or Palmyra (Borassus flabellifer) is a tropical fruit well known for its pulpy seeds and sweet sap. The fruit is also known as palmyra palm, doub palm, tala palm, toddy palm, wine palm, and ice apple. The ripen fruit pulp has medicinal uses in curing some inflammatory conditions of the skin and treatment of nausea, vomiting, and worm infestation (Arunachalam et al., 2011). Palm pulp is rich in sugars, vitamins (A, B, and C), carotenoids, and flavonoids (Vijayakumari $\boldsymbol{e t}$ al., 2014; Rout et al., 2014). The pulp is extracted by mechanical methods (Vijayakumari et al., 2014). The pulp and juice recovery can be increased by enzyme-assisted extraction processes (Rout et al., 2014; Vivek $\boldsymbol{e}$ t al., 2018) However, due to high sugar content, palm pulp, and juice ferment quickly, even at ambient conditions (Vijayakumari et al., 2014). Hence, storing of palm juice for a longer period is a challenging task. Converting the palm juice to powder can be an option to address the problem. The juice can be spray-dried to fruit powder under optimized conditions (Shishir et al., 2017; Vivek et al., 2021). The juice is atomized and sprayed on to hot air that dries the moisture of the liquid feed and forms powder (Krishnaiah et al., 2014; Vivek et al., 2021). However, the simple sugars present in the fruit juice melt at a higher temperature and make the powder sticky and hygroscopic. These problems can be addressed by adding wall-coating material that encloses the simple sugars and other nutrients present in the fruit juice (Chegini et al. 2007; Gharsallaoui et al. 2007; Phisut et al., 2012; Vivek et al., 2020; Vivek et al., 2021). In the present work, enzymatically extracted palm juice (Mohanty et al., 2018) was used for making powder. Maltodextrin and Gum Arabic were added as wall-material to address the problem of the stickiness of the final product. The spray drying process was optimized for additive concentration in the feed and inlet air temperature of the spray dryer. The feed rate and air aspiration rate of the spray dryer were kept constant. The palm powder so obtained had acceptable physicochemical properties. Results suggest that the process can be scaled up at the industrial level for the production of palm powder. This can open up avenues for developing processes and products for commercial use of the palm juice, which in turn can improve the economic condition and livelihood of the palm cultivators.

\section{MATERIALS AND METHODS}

\section{Feed preparation}

Ripe Palm is a seasonal fruit and is available only during the rainy season in tropical regions (Chaurasiya et al., 2014). Ripe palms (Borassus flabellifer), each of $900-1000 \mathrm{~g}$, were obtained from the local market (Fig.1a). Palm was cleaned with water and was peeled off. The seeds and the fibrous pulp were extracted manually. The fiber of the fruit is non-digestible and may block the nozzle of the spray dryer. Hence, separated from the pulp using a stainless steel scraper. The pulp (Fig.1b), so recovered, was pasteurized for $10 \mathrm{~min}$ at $90^{\circ} \mathrm{C}$ Palm juice was extracted from the pulp using Cellulase and Pectinase enzymes (Mohanty et al., 2018; Vivek et al., 2019). The enzymatic extraction process had juice yield of $87.9 \%$. The extracted juice had a total solid content of $12.9 \%$ with TSS of $12.8^{\circ}$ Brix. The total ascorbic acid content of the juice was $57 \pm 0.0003$ $\mu \mathrm{g} / \mathrm{ml}$. The juice had protein and sugar contents of 1.36 and $95 \pm 0.52 \mathrm{mg} / \mathrm{ml}$, respectively (Mohanty et al., 2018).

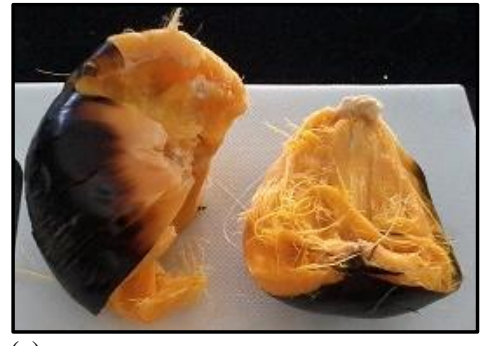

(a)

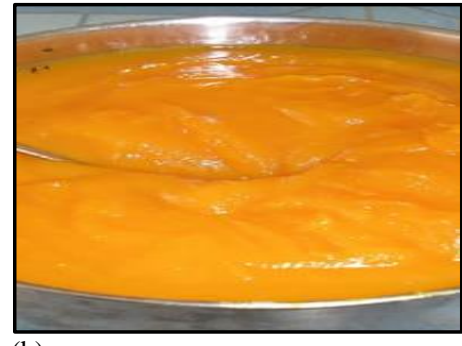

(b)
Figure 1 (a) Ripe Palm fruit and (b) Extracted pulp for experiments

\section{Spray drying of palm powder}

The palm juice $(100 \mathrm{ml})$ was mixed with $25-35 \mathrm{~g}$ of maltodextrin (DE 13-17, Sigma-Aldrich, India) and $10-20 \mathrm{~g}$ of gum arabic at different proportions to get proper encapsulation of fruit matrix during spray drying. Food grade gum arabic was obtained from the Indian Institute of Natural Resins and Gums, Ranchi, India. Lactose (15g, HiMedia, India) was also added to increase the solid content of the juice and lower the glass transition temperature during spray drying (Angel et al., 2009, Vivek et al., 2021). A lab-scale spray dryer (LSD-48, JISL, Mumbai, India) was used for the spray drying experiments. The inlet air temperature for the spray drying was varied between 130 to $150^{\circ} \mathrm{C}$ for various combinations of additives. On adding carrier wall materials at different proportions to the enzymatically extracted palm juice at different proportions, the total solid content increased to $23-48 \%$. The feed was fed to the spray dryer with a feed rate of 20 
$\mathrm{ml} /$ min (Muzaffar and Kumar, 2015). Spray drying was done at a fixed air pressure of 4 bar with an aspiration rate of $45 \%$ as per the instrument operating manual. The spray-dried powder was collected in the cyclone and collecting jar The powder was stored in airtight glass jars and was analyzed for various physical and chemical properties. The process parameters were optimized.

\section{Quality analysis of palm powder and reconstituted juice}

The experimental responses such as powder yield, moisture, water activity, solubility, colour change, and ascorbic acid content were determined following standard protocols described below.

\section{Powder yield}

The powder yield was calculated as the ratio of the weight of solid content of powder to the weight of the solid content of the feed (Cynthia et al., 2015). The yield percentage was calculated as

$$
P_{y}=\left(\frac{Q_{p}}{Q_{f}}\right) * 100
$$

Where $\mathrm{P}_{\mathrm{y}}$ is powder yield in $\%, \mathrm{Q}_{\mathrm{p}}$ is solid content of powder in grams, $\mathrm{Q}_{\mathrm{f}}$ is solid content of the feed in grams

\section{Ascorbic acid content}

Ascorbic acid (Vitamin C) contents of extracted and reconstituted juices were measured by the titrimetric method (Ioana et al., 2015). The direct titration of ascorbic acid with the dye 2,6-dichlorophenolindophenol gave qualitative measurements of vitamin $\mathrm{C}$ contents of the samples. The oxidative reaction of metaphosphoric-acetic acid with 2,6-dichlorophenolindophenol solution converts the ascorbic acid to dehydroascorbic acid, which is visually indicated by the titration method.

\section{Solubility time}

Solubility time was measured following the standard method suggested by Muzaffar and Kumar (2015). The time required to dissolve $2.5 \mathrm{~g}$ of powder completely in $100 \mathrm{~mL}$ of distilled water at $25^{\circ} \mathrm{C}$ was recorded and statistically analyzed.

\section{Moisture content}

The moisture content of the spray-dried palm powder was determined based on the AOAC method (Horwitz, 2000). Two grams of Palm powder was kept inside a hot air oven at a temperature of $105^{\circ} \mathrm{C}$ until a constant weight was obtained. Triplicates of the sample were examined to get a consistent result.

\section{Water activity}

The water activity of the palm powder was measured to evaluate the microbial growth during storage by placing $5 \mathrm{~g}$ of powder in the Water activity meter
(Rotronic, Switzerland) following the standard protocol (Muzaffar and Kumar, 2015)

\section{Reconstitution of Palm juice}

Reconstituted palm juice was prepared by dissolving palm powder in distilled water at $25^{\circ} \mathrm{C}$. The fruit powder was rehydrated to the same moisture content as the enzymatically extracted palm juice. To achieve the natural juice TSS of $12.8 \pm 0.5{ }^{0}$ Brix, the palm powder was reconstituted at a ratio of 1.3:10 (Rodríguez-Hernández et al., 2005).

\section{Colour difference of reconstituted juice}

Fresh palm juice reflects yellow colour. On exposure to high heat through spray drying, the colour of the powder changes. The colour of the extracted and reconstituted juices were measured using a colourimeter (Colorflex EZ, HunterLab, USA). The instrument was standardized following standard protocol, and the colour values were represented in terms of brightness/darkness $\left(\mathrm{L}^{*}\right)$ redness/greenness $\left(\mathrm{a}^{*}\right)$, and yellowness/blueness $\left(\mathrm{b}^{*}\right)$ (Ogbonna et al., 2013). The colour difference $(\Delta E)$ of the samples was calculated by

$$
\Delta E=\sqrt{\left(\Delta L^{*}\right)^{2}+\left(\Delta a^{*}\right)^{2}+\left(\Delta b^{*}\right)^{2}}
$$

\section{Statistical Analysis}

The spray drying and quality analysis experiments were designed using the response surface method (RSM) with central composite design (CCD) in DesignExpert ${ }^{\circledR}$ (Ver. 7.0.0) (Sagu et al., 2014, Lee et al., 2006). The variations in the responses due to independent factors were estimated by taking five center points (Bazaria and Kumar, 2018; Shishir et al., 2016). The experimental data were statistically analyzed, and regression models were developed. Additive concentration $\left(\mathrm{X}_{1}\right)$ and inlet temperature $\left(\mathrm{X}_{2}\right)$ were taken as independent variables. In the case of mixed additive treatments, maltodextrin concentration $\left(\mathrm{X}_{1}\right)$, gum Arabic concentration $\left(\mathrm{X}_{2}\right)$, and inlet temperature $\left(\mathrm{X}_{3}\right)$ were taken as independent variables. Powder yield $\left(\mathrm{Y}_{1}\right)$, powder moisture $\left(\mathrm{Y}_{2}\right)$, water activity $\left(\mathrm{Y}_{3}\right)$, solubility $\left(\mathrm{Y}_{4}\right)$, ascorbic acid content $\left(\mathrm{Y}_{5}\right)$, and colour change $\left(\mathrm{Y}_{6}\right)$ of spraydried palm powder samples were measured as dependent variables or responses and are shown in Table 1 (a), (b) and (c). These values were related to the coded variables $\left(\mathrm{X}_{\mathrm{i}}\right.$, where $\mathrm{i}=1,2,3$, and 4$)$ by a second-degree polynomial equation (Lee et al., 2006; Singh et al., 2012) as below:

$$
Y=b_{0}+\Sigma b_{i} X_{i}+\Sigma b_{i i} X_{i}^{2}+\Sigma b_{i j} X_{i} X_{j}
$$

Where $Y$ is the response, $X_{i}$ and $X_{j}$ are the levels of variables, $b_{0}$ is the constant, $b_{i}$ is the linear coefficient, $b_{i i}$ is the quadric term, and $b_{i j}$ is the coefficient of the interaction terms. Analysis of variance (ANOVA) was performed, and regression coefficients for linear, quadratic, and interaction terms were determined. Contour graphs were drawn for moisture content, water activity, solubility, ascorbic acid content, colour difference, and powder yield using the regression models and coefficients. The coefficients of determination and regression, and their

\begin{tabular}{|c|c|c|c|c|c|c|c|c|c|c|}
\hline \multirow{3}{*}{ Sl No } & \multicolumn{4}{|c|}{ Independent Variables } & \multicolumn{6}{|c|}{ Dependent Variables } \\
\hline & \multicolumn{2}{|c|}{ Maltodextrin,g (X1) } & \multicolumn{2}{|c|}{$\begin{array}{c}\text { Inlet Temp., }{ }^{\circ} \mathrm{C} \\
\text { (X2) }\end{array}$} & \multirow[t]{2}{*}{$\begin{array}{l}\text { Powder } \\
\text { Yield,\% } \\
\text { (Y1) }\end{array}$} & \multirow[t]{2}{*}{$\begin{array}{l}\text { Moisture, } \\
\%(\mathrm{Y} 2)\end{array}$} & \multirow[t]{2}{*}{$\begin{array}{c}\text { Water } \\
\text { Activity } \\
\text { (Y3) }\end{array}$} & \multirow[t]{2}{*}{$\begin{array}{l}\text { Solubility, } \\
\text { secs (Y4) }\end{array}$} & \multirow[t]{2}{*}{$\begin{array}{c}\text { Ascorbic Acid } \\
(\mu \mathrm{g} / \mathrm{ml})(\mathrm{Y} 5)\end{array}$} & \multirow[t]{2}{*}{$\begin{array}{c}\text { Juice } \\
\text { Colour, } \Delta \mathrm{E} \\
\text { (Y6) }\end{array}$} \\
\hline & Coded & Actual & Coded & Actual & & & & & & \\
\hline 1 & 0 & 30 & 1.4 & 152 & 63 & 3.8 & 0.295 & 40.0 & 50.0 & 15.5 \\
\hline 2 & 0 & 30 & 0 & 145 & 59 & 4.2 & 0.275 & 42.5 & 52.5 & 15.0 \\
\hline 3 & -1 & 25 & 1 & 150 & 60 & 4.1 & 0.345 & 42.0 & 50.0 & 16.0 \\
\hline 4 & -1.4 & 22.9 & 0 & 145 & 57 & 4.1 & 0.345 & 52.5 & 50.75 & 17.5 \\
\hline 5 & -1 & 25 & -1 & 140 & 54 & 4.1 & 0.310 & 42.5 & 55.25 & 20.0 \\
\hline 6 & 1 & 35 & -1 & 140 & 60 & 4.15 & 0.275 & 25.0 & 59.0 & 17.5 \\
\hline 7 & 0 & 30 & 0 & 145 & 59 & 4.5 & 0.284 & 50.0 & 52.0 & 15.7 \\
\hline 8 & 0 & 30 & 0 & 145 & 58.5 & 4.4 & 0.295 & 47.5 & 52.0 & 16.0 \\
\hline 9 & 1 & 35 & 1 & 150 & 64 & 3.5 & 0.261 & 42.5 & 50.0 & 16.32 \\
\hline 10 & 0 & 30 & 0 & 145 & 59 & 4.2 & 0.268 & 42.5 & 52.5 & 15.5 \\
\hline 11 & 1.4 & 37 & 0 & 145 & 62.5 & 3.6 & 0.265 & 39.0 & 54.5 & 15.0 \\
\hline 12 & 0 & 30 & -1.4 & 138 & 55 & 4.4 & 0.261 & 29.0 & 57.0 & 18.0 \\
\hline 13 & 0 & 30 & 0 & 145 & 59 & 4.1 & 0.295 & 50.0 & 52.0 & 15.3 \\
\hline
\end{tabular}
significances for each treatment are shown in Table 2 (a), (b) and (c).

Table 1(a) The central composite experimental design (in the coded level of two variables) for maltodextrin assisted spray drying of palm juice 
Table 1(b) The central composite experimental design (in coded level of two variables) for gum arabic assisted spray drying of palm juice

\begin{tabular}{|c|c|c|c|c|c|c|c|c|c|c|}
\hline \multirow{3}{*}{ Sl No } & \multicolumn{4}{|c|}{ Independent Variables } & \multicolumn{6}{|c|}{ Dependent Variables } \\
\hline & \multicolumn{2}{|c|}{ Gum arabic, g (X1) } & \multicolumn{2}{|c|}{$\begin{array}{c}\text { Inlet Temp. }{ }^{0} \mathrm{C} \\
(\mathrm{X} 2)\end{array}$} & \multirow{2}{*}{$\begin{array}{l}\text { Powder } \\
\text { Yield,\% } \\
\text { (Y1) }\end{array}$} & \multirow{2}{*}{$\begin{array}{c}\text { Moisture, } \\
\%(\mathrm{Y} 2)\end{array}$} & \multirow{2}{*}{$\begin{array}{c}\text { Water } \\
\text { Activity } \\
\text { (Y3) }\end{array}$} & \multirow{2}{*}{$\begin{array}{l}\text { Solubility, } \\
\text { secs (Y4) }\end{array}$} & \multirow{2}{*}{$\begin{array}{l}\text { Ascorbic Acid } \\
(\mu \mathrm{g} / \mathrm{ml})(\mathrm{Y} 5)\end{array}$} & \multirow{2}{*}{$\begin{array}{c}\text { Juice Colour, } \\
\qquad \mathrm{E}(\mathrm{Y} 6)\end{array}$} \\
\hline & Coded & Actual & Coded & Actual & & & & & & \\
\hline 1 & 0 & 15 & 1.4 & 142 & 68.4 & 3.30 & 0.265 & 37.2 & 57.6 & 26.4 \\
\hline 2 & 1 & 20 & -1 & 130 & 69.2 & 3.35 & 0.270 & 42.0 & 57.6 & 27.5 \\
\hline 3 & 1 & 20 & 1 & 140 & 70.0 & 3.30 & 0.290 & 45.0 & 56.3 & 28.4 \\
\hline 4 & 0 & 15 & 0 & 135 & 65.1 & 3.80 & 0.275 & 38.5 & 54.9 & 25.1 \\
\hline 5 & -1 & 10 & -1 & 130 & 64.5 & 4.12 & 0.251 & 37.2 & 52.6 & 21.6 \\
\hline 6 & -1 & 10 & 1 & 140 & 65.7 & 3.74 & 0.262 & 36.5 & 53.8 & 22.8 \\
\hline 7 & 1.4 & 22 & 0 & 135 & 72.4 & 3.20 & 0.280 & 43.3 & 58.2 & 28.8 \\
\hline 8 & -1.4 & 7.9 & 0 & 135 & 62.7 & 4.10 & 0.241 & 35.7 & 51.9 & 21.2 \\
\hline 9 & 0 & 15 & -1.4 & 128 & 67.2 & 3.90 & 0.278 & 35.4 & 54.6 & 23.7 \\
\hline 10 & 0 & 15 & 0 & 135 & 68.4 & 3.50 & 0.283 & 36.7 & 55.9 & 27.5 \\
\hline 11 & 0 & 15 & 0 & 135 & 69.5 & 3.70 & 0.291 & 37.2 & 57.2 & 26.9 \\
\hline 12 & 0 & 15 & 0 & 135 & 68.4 & 3.65 & 0.279 & 37.4 & 56.1 & 28.1 \\
\hline 13 & 0 & 15 & 0 & 135 & 67.5 & 3.81 & 0.275 & 38.3 & 57.6 & 27.5 \\
\hline
\end{tabular}

Table 1(c) The central composite experimental design (in coded level of two variables) for combined additive assisted spray drying of palm juice

\begin{tabular}{|c|c|c|c|c|c|c|c|c|c|c|c|c|}
\hline \multirow{3}{*}{ Sl No } & \multicolumn{6}{|c|}{ Independent Variables } & \multicolumn{6}{|c|}{ Dependent Variables } \\
\hline & \multicolumn{2}{|c|}{$\begin{array}{l}\text { Maltodextrin (g) } \\
\text { (X1) }\end{array}$} & \multicolumn{2}{|c|}{ Gum Arabic (g) (X2) } & \multicolumn{2}{|c|}{$\begin{array}{l}\text { Inlet Temp. }\left({ }^{0} \mathrm{C}\right) \\
(\mathrm{X} 3)\end{array}$} & \multirow{2}{*}{$\begin{array}{l}\text { Powder } \\
\text { Yield \% } \\
\text { (Y1) }\end{array}$} & \multirow{2}{*}{$\begin{array}{c}\text { Moisture } \\
\%(\mathrm{Y} 2)\end{array}$} & \multirow{2}{*}{$\begin{array}{c}\text { Water } \\
\text { Activity } \\
\text { (Y3) }\end{array}$} & \multirow{2}{*}{$\begin{array}{l}\text { Solubility, } \\
\text { secs (Y4) }\end{array}$} & \multirow{2}{*}{$\begin{array}{l}\text { Ascorbic } \\
\text { Acid }(\mu \mathrm{g} \\
/ \mathrm{ml})(\mathrm{Y} 5)\end{array}$} & \multirow{2}{*}{$\begin{array}{c}\text { Juice } \\
\text { Colour, } \\
\Delta \mathrm{E}(\mathrm{Y} 6)\end{array}$} \\
\hline & Coded & Actual & Coded & Actual & Coded & Actual & & & & & & \\
\hline 1 & 0 & 27.5 & 0 & 12.5 & 1.68 & 147 & 67.2 & 3.75 & 0.29 & 34.7 & 54.00 & 20.51 \\
\hline 2 & 0 & 27.5 & 0 & 12.5 & 0 & 130 & 64.8 & 3.7 & 0.32 & 35.4 & 57.32 & 22.18 \\
\hline 3 & 1.68 & 31.7 & 0 & 12.5 & 0 & 130 & 65.8 & 3.1 & 0.28 & 31.3 & 56.70 & 20.49 \\
\hline 4 & 0 & 27.5 & 1.68 & 16.7 & 0 & 130 & 60.3 & 3.7 & 0.30 & 36.2 & 55.12 & 21.83 \\
\hline 5 & -1 & 25.0 & -1 & 10.0 & 1 & 140 & 56.5 & 3.56 & 0.35 & 32.8 & 56.00 & 18.22 \\
\hline 6 & 1 & 30.0 & 1 & 15.0 & 1 & 140 & 67.2 & 3.6 & 0.23 & 35.5 & 55.60 & 23.12 \\
\hline 7 & 1 & 30.0 & -1 & 10.0 & 1 & 140 & 62.7 & 3.35 & 0.28 & 31.5 & 54.60 & 19.10 \\
\hline 8 & 1 & 30.0 & 1 & 15.0 & -1 & 120 & 58.5 & 3.45 & 0.30 & 32.4 & 57.20 & 23.24 \\
\hline 9 & 0 & 27.5 & 0 & 12.5 & -1.68 & 113 & 56.1 & 3.6 & 0.35 & 33.7 & 57.14 & 21.56 \\
\hline 10 & 0 & 27.5 & 0 & 12.5 & 0 & 130 & 64.5 & 3.7 & 0.34 & 34.6 & 56.50 & 21.69 \\
\hline 11 & -1.68 & 23.3 & 0 & 12.5 & 0 & 130 & 62.1 & 3.48 & 0.33 & 31.74 & 58.23 & 19.62 \\
\hline 12 & 0 & 27.5 & 0 & 12.5 & 0 & 130 & 66.5 & 3.69 & 0.31 & 34.9 & 57.69 & 20.96 \\
\hline 13 & 0 & 27.5 & -1.68 & 8.3 & 0 & 130 & 57.5 & 3.45 & 0.38 & 34.0 & 55.20 & 17.90 \\
\hline 14 & -1 & 25.0 & 1 & 15.0 & -1 & 120 & 57.2 & 3.56 & 0.35 & 32.3 & 58.23 & 19.89 \\
\hline 15 & 1 & 30.0 & -1 & 10.0 & -1 & 120 & 61.2 & 3.31 & 0.34 & 31.9 & 55.30 & 19.26 \\
\hline 16 & -1 & 25.0 & 1 & 12.0 & 1 & 140 & 63.8 & 3.67 & 0.31 & 33.9 & 55.81 & 21.40 \\
\hline 17 & 0 & 27.5 & 0 & 12.5 & 0 & 130 & 62.5 & 3.68 & 0.31 & 34.9 & 56.39 & 22.00 \\
\hline 18 & -1 & 25.0 & -1 & 10.0 & -1 & 120 & 55.2 & 3.74 & 0.37 & 34.3 & 59.13 & 20.13 \\
\hline 19 & 0 & 27.5 & 0 & 12.5 & 0 & 130 & 65.9 & 3.61 & 0.34 & 34.6 & 56.38 & 22.48 \\
\hline 20 & 0 & 27.5 & 0 & 12.5 & 0 & 130 & 66.5 & 3.7 & 0.31 & 34.8 & 55.62 & 23.15 \\
\hline
\end{tabular}

\section{RESULTS AND DISCUSSION}

\section{Effect of spray drying with maltodextrin on response variables}

\section{Powder yield}

The linear terms of the independent variable had a significant effect on powder yield at $p<0.001$. Spray-dried powder yield was higher with increased additive concentration and higher inlet temperature. The interaction terms showed an insignificant effect on powder yield, whereas the quadratic term of additive concentration had a significant effect $(p<0.05)$ on the yield. The presence of additives in palm juice is contributing to the higher yield of palm powder (Goula et al., 2010, Vivek et al., 2020). Response surfaces of powder yield are shown in Fig. 2(a). An optimized spray-dried powder yield of $59.55 \pm 0.55 \%$ (w/w) was achieved with 25 grams of maltodextrin and inlet temperature of $148^{\circ} \mathrm{C}$. The data fits the equation extremely well with the highest $R^{2}$, Adj. $R^{2}$ and Predicted $R^{2}$ (Table 2a).

\section{Moisture content}

The moisture content plays a crucial role in controlling microbial growth and extending the shelf life of the powder. The effect of spray drying with maltodextrin on the moisture content of the palm powder is shown in Table 2(a) The linear terms for additive concentration and temperature showed a significant difference at $p<0.05$. The moisture content of the palm powder decreased with an increase in inlet temperature and additive concentration. This may be due to the exposure of the juice to high temperature during drying. Similar results were observed for watermelon, cactus pear, and orange (Rodríguez-Hernández et al. 2005; Quek et al. 2007). The interaction terms showed a significant difference at $p<0.05$. While the quadratic term of additives concentration showed a significant difference at $p<0.01$. The response surfaces of process variables and their interactions for moisture content are shown in Fig. 2(b). The data fits the equation extremely well with the highest $R^{2}$, Adj. $R^{2}$ and Predicted $R^{2}$ (Table 2a).

\section{Water activity}

The linear terms, i.e., additive concentration and temperature, showed significan differences at $p<0.001$. The water activity of the powder decreased with an increase in inlet temperature and additive concentration. This may be due to the decrease in moisture content and the influence of encapsulating and anti-caking agents. No significant decrease in water activity was observed for the interaction terms. The quadratic term for additive concentration had a significant difference at $p<0.05$. Similar results were observed for pineapple juice with maltodextrin as a wall material (Goula et $\boldsymbol{a l}$., 2010). The response surfaces of process variables 
and their interactions for water activity are shown in Fig. 2(c). The data fits the equation extremely well with the highest $\mathrm{R}^{2}$, Adj. $\mathrm{R}^{2}$ and Predicted $\mathrm{R}^{2}$ (Table 2a).

\section{Solubility time}

The spray-dried palm powder has more solubility time. The linear terms for independent factors showed significant differences at $p<0.01$. The increased solubility time might be due to the presence of a high amount of additives that makes it difficult to get soluble in water (Rodríguez-Hernández et al., 2005). The interaction terms showed insignificant differences, whereas the quadratic term for additive concentration shows a significance at $p<0.01$. The effects of independent variables on solubility are shown in Fig. 2(d). The data fits the equation extremely well with the highest $R^{2}$, Adj. $R^{2}$ and Predicted $R^{2}$ (Table 2a).

\section{Ascorbic acid content}

The linear terms for additive concentration $(p<0.01)$ and inlet temperature $(p<0.001)$ had a significant effect on ascorbic acid content. Ascorbic acid content decreased with an increase in the drying temperature. Palm powder made with $25 \mathrm{~g}$ of maltodextrin and spray-dried at $140^{\circ} \mathrm{C}$ inlet temperature had the maximum ascorbic acid content. The high ascorbic acid content of the powder could be due to efficient encapsulation by maltodextrin that protects it from degradation at a higher temperature. Similar results have been reported for spray-dried guava and passion fruit powders (Ioana et al., 2015; Bazaria et al., 2018). The interaction and the quadratic terms of the independent variables had insignificant effects on the response. The response surface for ascorbic acid content is shown in Fig. 2(e).
The data fits the equation extremely well with the highest $R^{2}$, Adj. $R^{2}$ and Predicted $\mathrm{R}^{2}$ (Table 2a).

\section{Colour of reconstituted palm juice}

The spray-dried palm powder was used to make reconstituted juice and was compared with the palm juice. The physicochemical properties of the reconstituted juice are given in Table 3. The linear terms of additive concentration and inlet temperature showed significant differences at $p<0.01$ on the colour of the reconstituted juice. The interaction and quadratic term of additive concentration had an insignificant effect on the response, whereas the quadratic term for temperature had a significant effect at $p<0.01$. The colour difference between original and reconstituted juices decreased with increased maltodextrin in the feed. This may be due to proper encapsulation of palm powder during spray drying that preserves natural colour pigments in the process. The additive is of a lighter colour, which also may have added to the reason for colour difference (Rodríguez-Hernández et al., 2005; Goula et al., 2010; Bazaria et al., 2018). The response surfaces for Colour difference is shown in Fig. 2(f). The data fits the equation extremely well with the highest $\mathrm{R}^{2}$, Adj. $\mathrm{R}^{2}$ and Predicted $R^{2}$ (Table 2a).

The powder obtained under optimum conditions using maltodextrin had a moisture content of $4.1 \pm 0.15 \%(\mathrm{db})$, water activity of $0.33 \pm 0.011$, solubility time of $46.09 \pm 0.06$ seconds, and Ascorbic Acid content $(50 \pm 0.0026 \mu \mathrm{g}$ of $\mathrm{AA} / \mathrm{ml})$ The reconstituted juice had a colour change $(\Delta \mathrm{E})$ of $15.92 \pm 0.02$.

Table 2(a) Coefficients of regression, $\mathrm{R}^{2}$ values for the different Responses for Maltodextrin aided spray drying of palm juice

\begin{tabular}{lcccccc}
\hline $\begin{array}{l}\text { Regression } \\
\text { Coefficient }\end{array}$ & Moisture & $\begin{array}{c}\text { Water } \\
\text { Activity }\end{array}$ & Solubility & $\begin{array}{c}\text { Ascorbic } \\
\text { Acid }\end{array}$ & $\begin{array}{c}\text { Colour } \\
\text { change }\end{array}$ & Yield \\
\hline $\mathrm{b}_{0}$ & 4.28 & 0.28 & 46.5 & 52.20 & 15.5 & 58.9 \\
$\mathrm{~b}_{1}$ & $-0.16^{*}$ & $-0.029^{* * *}$ & $-4.51^{* *}$ & $1.13^{* *}$ & -0.71 & $2.22^{* * *}$ \\
$\mathrm{~b}_{2}$ & $-0.19^{*}$ & 0.86 & $4.07^{* *}$ & $-3.02^{* * *}$ & $-1.09^{* *}$ & $2.66^{* * *}$ \\
$\mathrm{~b}_{12}$ & $-0.16^{*}$ & -0.012 & 4.50 & -0.94 & 0.70 & -0.50 \\
$\mathrm{~b}_{1}{ }^{2}$ & $0.22^{* *}$ & $0.012^{*}$ & -0.91 & 0.34 & 0.61 & $0.46^{*}$ \\
$\mathrm{~b}_{2}{ }^{2}$ & -0.093 & -0.113 & -6.53 & 0.34 & $0.86^{*}$ & 0.081 \\
$\mathrm{R}^{2}$ & 0.89 & 0.923 & 0.909 & 0.963 & 0.883 & 0.989 \\
Adjusted $\mathrm{R}^{2}$ & 0.81 & 0.87 & 0.84 & 0.93 & 0.80 & 0.98 \\
Predicted $\mathrm{R}^{2}$ & 0.78 & 0.78 & 0.78 & 0.75 & 0.75 & 0.93 \\
\hline
\end{tabular}

$\mathrm{b}$ represents the coefficients of equations different responses with $\mathrm{b}_{0}$ the constant term; $\mathrm{b}_{1}$, and $\mathrm{b}_{2}$ the linear effects $(1$, and 2 respectively the concentration, temperature); $\mathrm{b}_{1}{ }^{2}, \mathrm{~b}_{2}{ }^{2}$ are the quadratic effects; and $\mathrm{b}_{12}$ is the interactions.

"Significant at $p \leq 0.05,{ }^{* *}$ Significant at $p \leq 0.01,{ }^{* * *}$ Significant at $p \leq 0.001$.

Effect of spray drying with gum arabic on response variables

\section{Powder yield}

There was a significant effect $(p<0.001)$ of linear terms of additive concentration on the yield of powder. The response surface plots (Fig...3 (a)) indicates increased powder yield at increased additive concentration and inlet temperature. The higher amount of gum arabic additive encapsulates the palm powder more effectively at higher temperatures resulting in higher yield. Similar results have been reported for spray-dried pineapple and mulberry powders (Fazaeli $\boldsymbol{e}$ t al., 2012; Jittanit et al., 2010, Vivek et al., 2020). The data fits the equation extremely well with the highest $\mathrm{R}^{2}$, Adj. $\mathrm{R}^{2}$ and Predicted $\mathrm{R}^{2}$ (Table $2 \mathrm{~b}$ ). The optimized value of powder yield was $65.23 \pm 0.17 \%(w / w)$ at $140^{\circ} \mathrm{C}$ inlet temperature with 10 grams of gum Arabic additive having the desirability of greater than 0.8

\section{Moisture content}

The linear terms, i.e., additive concentration and temperature, had significant effects on the moisture content of the powder at $p<0.01$. The moisture content of powder decreased with an increase in temperature and carrier concentration. At higher temperatures, moisture removal was more. Similar results have been reported for mulberry and pomegranate powders with gum arabica (Fazaeli $\boldsymbol{e t}$ al., 2012). The response surfaces of process variables and their interactions are illustrated in Fig. 3 (b). The data fits the equation extremely well with the highest $R^{2}$, Adj. $R^{2}$ and Predicted $R^{2}$ (Table $2 b$ ).

\section{Water activity}

As the moisture content of the spray-dried palm powder decreased with gum arabica as an additive, the water activity also decreased. The linear term ( $p<$ $0.01)$ and quadrative term $(p<0.05)$ of additive concentration had a significant difference (Table 2b). The anti-caking agent, magnesium carbonate, and gum arabica decreased the availability of water in the palm powder. It also lowers the hygroscopicity of the powder. Gum arabic encapsulates the powder particles and stabilizes it (Yousefi et al., 2011). The optimized value of the water activity of the palm powder with gum Arabic was $0.25 \pm 0.014$. The response surfaces of water activity are illustrated in Fig. 3 (c). The data fits the equation extremely well with the highest $R^{2}$, Adj. $R^{2}$ and Predicted $R^{2}$ (Table $2 b$ )

\section{Solubility time}

The linear term for additive concentration had a significant effect on the solubility of the powder at $p<0.01$. Gum arabic decreases the solubility of the spray-dried palm powder. The solubility time of powder increased with an increase in additive concentration (Fig. 3(d)). This increase in solubility time of the powder may be attributed to the lower soluble properties of Gum arabic. Similar results have been reported for pineapple and watermelon powder spray dried with gum Arabic (Quek et al., 2007 and Gabas et al., 2007). The interaction terms and quadratic term for additive concentration $(p<0.05)$ show a positive effect on solubility time, confirming the results. The data fits the equation extremely well with the highest $R^{2}$, Adj. $R^{2}$ and Predicted $R^{2}$ (Table $2 b$ ). 

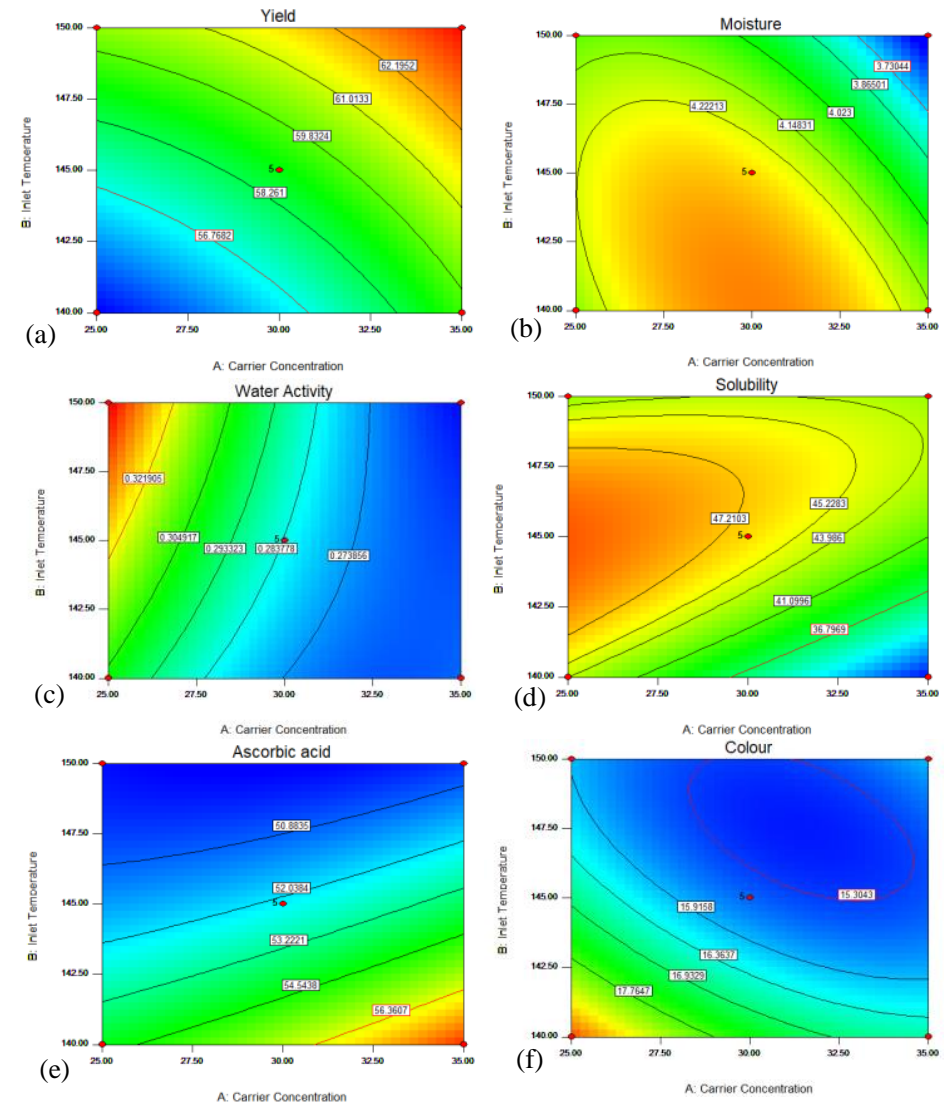

Moisture Content (c) Water activity (d) Solubility Time (e) Ascorbic Acid Content (f) Colour Change

\section{Ascorbic acid content}

The linear term for additive concentration had a significant effect on the ascorbic acid content of the palm powder at $p<0.01$. The response surfaces of this parameter are shown in Fig. 3(e). Ascorbic acid content increased with an increase in additive concentration. In the presence of more additive, the ascorbic acid is encapsulated well and less effected on exposure to a higher temperature. The quadratic term for additive concentration also had a significant difference at $\mathrm{p}<0.05$, suggesting less degradation Ascorbic acid in the presence of a higher amount of additive. These additives encapsulate ascorbic acid and other antioxidants present in the fruit juice matrix (Quek et al., 2007, Jittanit et al., 2010, Vivek et al., 2020). The data fits the equation extremely well with the highest $\mathrm{R}^{2}$, Adj. $\mathrm{R}^{2}$ and Predicted $\mathrm{R}^{2}$ (Table $2 b$ ).

\section{Colour of the reconstituted juice}

The fruit powder was reconstituted, and the colour was measured. The other physicochemical properties of the reconstituted juice are given in Table 3. The linear term, i.e., additive concentration had a significant effect $(p<0.01)$ on the colour difference of the reconstituted juice. The response surface for this parameter is shown in Fig. 3(f). There was a high colour difference when a higher amount of gum arabic was added to the feed. This may be due to the effect of the natural brown colour of the additive (Gabas et al., 2007; Vivek $\boldsymbol{e t}$ al., 2020). The quadratic terms of additive concentration and inlet temperature for this parameter had significance differences $(p<0.05)$, indicating changes in powder colour at a higher temperature in the presence of gum arabic. The data fits the equation extremely well with the highest $R^{2}$, Adj. $R^{2}$ and Predicted $R^{2}$ (Table $2 b$ ). The optimized value of the colour difference $(\Delta \mathrm{E})$ was $23.08 \pm 0.08$.

The Palm juice powder with gum Arabic additive had a moisture content of $3.69 \pm 0.22 \%(\mathrm{db})$, water activity of $0.25 \pm 0.014$, Ascorbic Acid content of $54 \pm 0.0015 \mu \mathrm{g}$ of AA $/ \mathrm{ml}$ with solubility time of $35.7 \pm 0.03$ seconds.

Figure 2 Response surfaces of Maltodextrin aided spray drying representing the effect of Additive Concentration and Inlet Temperature on (a) Powder Yield (b)

Table 2(b) Coefficients of regression, $\mathrm{R}^{2}$ values for the different Responses for Gum Arabic aided spray drying of palm juice

\begin{tabular}{lcccccc}
\hline Regression Coefficient & Moisture & Water Activity & Solubility & Ascorbic Acid & $\begin{array}{c}\text { Colour } \\
\text { change }\end{array}$ & Yield \\
\hline $\mathrm{b}_{0}$ & 3.69 & 0.28 & 37.62 & 56.34 & 27.02 & 67.78 \\
$\mathrm{~b}_{1}$ & $-0.31^{* * *}$ & $0.013^{* *}$ & $3.01^{* *}$ & $2.05^{* *}$ & $2.78^{* * * *}$ & $2.84^{* * *}$ \\
$\mathrm{~b}_{2}$ & $-0.16^{* *}$ & 0.577 & 0.61 & 0.52 & 0.74 & 0.46 \\
$\mathrm{~b}_{12}$ & -0.083 & 0.25 & 0.93 & -0.63 & -0.075 & -0.10 \\
$\mathrm{~b}_{1}{ }^{2}$ & 0.020 & $-0.48^{*}$ & $1.51^{*}$ & $-0.77^{*}$ & $-1.00^{*}$ & -0.20 \\
$\mathrm{~b}_{2}{ }^{2}$ & -0.045 & -0.98 & -0.091 & -0.25 & $-0.97^{*}$ & -0.071 \\
$\mathrm{R}^{2}$ & 0.92 & 0.80 & 0.87 & 0.84 & 0.93 & 0.82 \\
Adjusted $^{2}$ & 0.86 & 0.65 & 0.78 & 0.73 & 0.88 & 0.70 \\
Predicted $\mathrm{R}^{2}$ & 0.76 & 0.62 & 0.76 & 0.68 & 0.86 & 0.67 \\
\hline $\mathrm{b}$ Represents the cofficients & of
\end{tabular}

$\mathrm{b}$ Represents the coefficients of equations different responses with $\mathrm{b}_{0}$ the constant term; $\mathrm{b}_{1}$, and $\mathrm{b}_{2}$ the linear effects

$\left(1\right.$, and 2 respectively the concentration, temperature); $\mathrm{b}_{1}{ }^{2}, \mathrm{~b}_{2}{ }^{2}$ are the quadratic effects; and $\mathrm{b}_{12}$ is the interactions.

${ }^{*}$ Significant at $p \leq 0.05,{ }^{* *}$ Significant at $p \leq 0.01,{ }^{* * *}$ Significant at $p \leq 0.001$.

Effect of spray drying with combined maltodextrin and gum arabic on response variables

\section{Powder yield}

All the linear terms of the equation, such as gum Arabic $(p<0.05)$, maltodextrin $(p<0.01)$, and temperature $(p<0.001)$, had significant effects on powder yield. The powder yield increased with an increase in the additive concentrations and temperature (Fig. 4(a)). Efficient encapsulation by the additives plays an important role in increasing powder yield even at a higher temperature (Muzaffar et al., 2018; Vivek et al., 2020). The solid contents of both the additives also contributed to a higher yield of palm powder. The quadratic terms of gum arabic $(p<0.001)$ and temperature $(p<0.01)$ had significant effects on powder yield. The spray drying process was optimized at $140^{\circ} \mathrm{C}$ of inlet temperature, 30 grams of maltodextrin, and 10 grams of gum arabic with product desirability of 1 . Under the optimized conditions, the powder yield was $63.5 \pm 0.29 \%(\mathrm{w} / \mathrm{w})$. The data fitted the equation extremely well with the highest $\mathrm{R}^{2}$, Adj. $\mathrm{R}^{2}$ and Predicted $\mathrm{R}^{2}$ (Table $2 \mathrm{c}$ ).

\section{Moisture content}

Maltodextrin and gum Arabic was used for spray drying of palm juice. Fig. 4 (b) shows the graphs of the response surfaces of moisture content. The linear terms of both the additives and inlet temperature $(p<0.01)$ had significant effects on the moisture content of the powder. The moisture content of palm powder decreased with an increase in additives concentration. The combined effect of two additives helped in better microencapsulation of the fruit juice matrix. The interaction terms of the combined effect of gum arabic concentration-inlet temperature had a significant effect on the moisture content of the powder at $p<0.01$, whereas the interaction terms of maltodextrin concentration-inlet temperature, had a significant effect at $p<0.05$. Gum arabic was more effective in decreasing the moisture content of the palm powder than maltodextrin. The quadratic terms of maltodextrin concentration $(p<0.001)$ and gum arabic concentration $(p<0.05)$ had significant effects on the moisture content of the powder. The presence of a higher amount of maltodextrin and gum Arabic in palm juice reduces the moisture content of palm powder at a higher temperature. This may be due to the anti-hygroscopic property of these additives. Similar results have been reported for spray-dried sugarcane and mulberry powders (Largo et al., 2015; Fazaeli $\boldsymbol{e}$ al., 2012). The data fits the equation extremely well with the highest $R^{2}$, Adj. $R^{2}$ and Predicted $\mathrm{R}^{2}$ (Table $2 \mathrm{c}$ ).

\section{Water activity}

The linear terms, i.e., maltodextrin $(p<0.001)$, gum Arabic $(p<0.01)$, and inlet temperature $(p<0.01)$, had significant effects on water activity of the spray-dried 
powder. The response surface plots (Fig. 4 (c)) indicate a decreased water activity with an increased concentration of combined additives and inlet temperature This is due to the decreased moisture content of the spray-dried palm powder. Similar results were observed by Largo et al. (2015) and Quek et al. (2007) for spray-dried powders of watermelon, sugarcane, and cactus pear fruits with a lower water activity $(<0.5)$. The data fits the equation extremely well with the highest $\mathrm{R}^{2}$, Adj. $\mathrm{R}^{2}$ and Predicted $\mathrm{R}^{2}$ (Table $2 \mathrm{c}$ ).
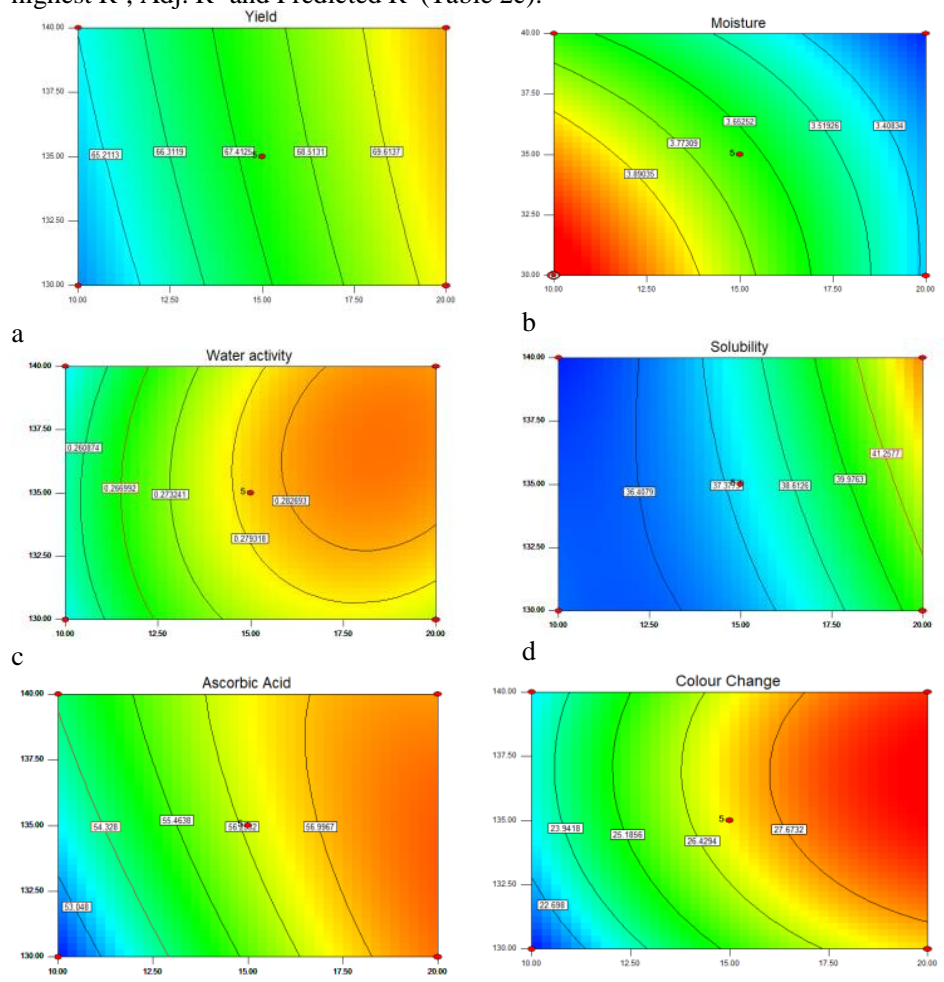

f

Figure 3 Response surfaces of Gum Arabic aided spray drying representing the effect of Additive Concentration and Inlet Temperature on (a) Powder Yield (b)
Moisture Content (c) Water activity (d) Solubility Time (e) Ascorbic Acid Content (f) Colour Change

\section{Solubility time}

Significance differences were observed for linear terms of gum arabic $(p<0.01)$, inlet temperature $(p<0.01)$, and maltodextrin $(p<0.05)$ on solubility time. The response surface of solubility is shown in Fig. 4(d). The solubility time of the powder increased as the additive concentration increased. However, maltodextrin had a lesser effect on the solubility time of the powder than gum Arabic. The interaction terms of maltodextrin-inlet temperature $(p<0.05)$, maltodextrin-gum Arabic $(p<0.01)$, and gum Arabic-inlet temperature $(p<0.001)$ had significant effects on solubility time. With a higher concentration of additives, the powder had higher solubility time. This may be due to the lower water-soluble and hygroscopic properties of the additives. Similar results were observed during spray-drying sugarcane juice. The solubility time increased with inlet temperature and additive concentration (Largo et al., 2015 and Nishad et al., 2019). The data fits the equation extremely well with the highest $R^{2}$, Adj. $R^{2}$ and Predicted $R^{2}$ (Table 2c).

\section{Ascorbic acid content}

Linear terms of maltodextrin $(p<0.01)$ and temperature $(p<0.01)$ had significant effects on ascorbic acid content. However, gum Arabic had no significant effect on the ascorbic acid content when used in combination with maltodextrin. The response surface plots (Fig. 4(e)) indicates an increase of ascorbic acid content with increased additive concentration. The combination of both the additives improved the encapsulation of fruit matrix that protected the ascorbic acid in the powder even at a higher temperature (Muzaffar $\boldsymbol{e t}$ al., 2018). The ascorbic acid data fits the equation extremely well with the highest $\mathrm{R}^{2}$, Adj. $\mathrm{R}^{2}$ and Predicted $\mathrm{R}^{2}$ (Table 2c). The optimum value of ascorbic acid content while spray-drying with combined additives was $54 \pm 0.0003 \mu \mathrm{g}$ of $\mathrm{AA} / \mathrm{ml}$. This value was much higher than that obtained with individual additive.

\begin{tabular}{lllllll}
\multicolumn{6}{l}{ Table 2(c) Coefficients of regression, $\mathrm{R}^{2}$ values } & for the different Responses for the combined effect of additives on spray drying of palm juice \\
\hline Regression Coefficient & Moisture & Water activity & Solubility & Ascorbic Acid & Colour & Yield \\
\hline $\mathrm{b}_{0}$ & 3.68 & 0.32 & 34.88 & 56.64 & 22.07 & 65.15 \\
$\mathrm{~b}_{1}$ & $-0.11^{* * *}$ & $-0.023^{* * *}$ & $-0.20^{* *}$ & $-0.66^{* *}$ & 0.48 & $1.69^{* * *}$ \\
$\mathrm{~b}_{2}$ & $0.054^{* * *}$ & $-0.021^{* *}$ & $0.53^{* * *}$ & 0.12 & $1.29^{* * *}$ & $1.16^{*}$ \\
$\mathrm{~b}_{3}$ & $0.027^{* *}$ & $-0.021^{* *}$ & $0.33^{* *}$ & $-0.96^{* *}$ & -0.18 & $2.69^{* * *}$ \\
$\mathrm{~b}_{12}$ & $0.058^{* *}$ & -0.75 & $0.68^{* *}$ & 0.50 & $0.63^{*}$ & -0.94 \\
$\mathrm{~b}_{13}$ & $0.033^{*}$ & -0.75 & $0.33^{*}$ & 0.41 & 0.015 & 0.29 \\
$\mathrm{~b}_{23}$ & $0.050^{* * *}$ & -0.75 & $0.83^{* * *}$ & -0.024 & 0.43 & 1.56 \\
$\mathrm{~b}_{1}{ }^{2 *}$ & $-0.13^{* * *}$ & 0.036 & $-1.28^{* * *}$ & 0.38 & $-0.64^{*}$ & -0.62 \\
$\mathrm{~b}_{2}{ }^{2}$ & $-0.031^{*}$ & -0.339 & -0.014 & -0.43 & $-0.71^{*}$ & $-2.41^{* * *}$ \\
$\mathrm{~b}_{3}{ }^{2}$ & 0.883 & -0.732 & $-0.33^{* *}$ & -0.29 & -0.30 & $-1.44^{* *}$ \\
$\mathrm{R}^{2}$ & 0.96 & 0.913 & 0.968 & 0.867 & 0.891 & 0.925 \\
Adjusted $\mathrm{R}^{2}$ & 0.93 & 0.83 & 0.94 & 0.74 & 0.79 & 0.85 \\
Predicted $^{2}$ & 0.78 & 0.62 & 0.82 & 0.66 & 0.65 & 0.69 \\
\hline $\mathrm{b}$ Represen
\end{tabular}

$\mathrm{b}$ Represents the coefficients of equations different responses with $\mathrm{b}_{0}$ the constant term; $\mathrm{b}_{1}, \mathrm{~b}_{2}$, and $\mathrm{b}_{3}$ the linear effects $(1,2$, and 3 respectively the maltodextrin weight, gum arabic weight and temperature); $\mathrm{b}_{1}{ }^{2}, \mathrm{~b}_{2}{ }^{2}, \mathrm{~b}_{3}{ }^{2}$ are the quadratic effects; and $\mathrm{b}_{12}, \mathrm{~b}_{13}, \mathrm{~b}_{23}$ are different interactions.

${ }^{*}$ Significant at $p \leq 0.05,{ }^{* *}$ Significant at $p \leq 0.01,{ }^{* * *}$ Significant at $p \leq 0.001$.

Table 3 Comparative Studies of physicochemical properties of the control and reconstituted juices

\begin{tabular}{lcccc}
\hline Properties & $\begin{array}{c}\text { Optimized juice } \\
\text { (Control } \\
\text { Sample) }\end{array}$ & $\begin{array}{c}\text { Reconstituted } \\
\text { juice from MD } \\
\text { aided SD Powder }\end{array}$ & $\begin{array}{c}\text { Reconstituted juice } \\
\text { from GA aided SD } \\
\text { Powder }\end{array}$ & $\begin{array}{c}\text { Reconstituted juice } \\
\text { from MD and GA } \\
\text { aided SD Powder }\end{array}$ \\
\hline Moisture content $(\%)$ & $87.1 \pm 1.09^{\mathrm{c}}$ & $88.2 \pm 0.12^{\mathrm{a}}$ & $87.23 \pm 0.24^{\mathrm{c}}$ & $89.2 \pm 1.25^{\mathrm{d}}$ \\
\hline Total solid $(\%)$ & $12.9 \pm 0.17^{\mathrm{b}}$ & $12.71 \pm 0.63^{\mathrm{d}}$ & $12.82 \pm 0.22^{\mathrm{b}}$ & $12.90 \pm 0.23^{\mathrm{a}}$ \\
\hline Total soluble solid (Brix) & $12.8 \pm 0.0513^{\mathrm{a}}$ & $12.54 \pm 0.23^{\mathrm{b}}$ & $12.6 \pm 0.41^{\mathrm{a}}$ & $12.7 \pm 0.66^{\mathrm{b}}$ \\
\hline Total dissolved solids $(\mathrm{ppm})$ & $259.4 \pm 0.108^{\mathrm{c}}$ & $345.52 \pm 0.61^{\mathrm{b}}$ & $350.23 \pm 0.52^{\mathrm{a}}$ & $356.2 \pm 0.114^{\mathrm{b}}$ \\
\hline $\mathrm{pH}$ & $3.5 \pm 0.031^{\mathrm{a}}$ & $4.5 \pm 0.011^{\mathrm{a}}$ & $4.2 \pm 0.015^{\mathrm{c}}$ & $4.2 \pm 0.021^{\mathrm{b}}$ \\
\hline Ascorbic acid $(\mu \mathrm{g}$ of $\mathrm{AA} / \mathrm{ml})$ & $57 \pm 0.0003^{\mathrm{d}}$ & $51 \pm 0.0026^{\mathrm{c}}$ & $55 \pm 0.024^{\mathrm{a}}$ & $54 \pm 0.005^{\mathrm{a}}$ \\
\hline Protein $(\mathrm{mg} / \mathrm{ml})$ & $1.36 \pm 0.23^{\mathrm{d}}$ & $1.33 \pm 0.05^{\mathrm{a}}$ & $1.31 \pm 0.25^{\mathrm{b}}$ & $1.31 \pm 0.12^{\mathrm{c}}$ \\
\hline Fat\% & $0.45 \pm 0.13^{\mathrm{c}}$ & $0.42 \pm 0.04^{\mathrm{d}}$ & $0.45 \pm 0.11^{\mathrm{d}}$ & $0.41 \pm 0.25^{\mathrm{a}}$ \\
\hline Sugar $(\mathrm{mg} / \mathrm{ml})$ & $95 \pm 0.52^{\mathrm{a}}$ & $85.52 \pm 0.51^{\mathrm{c}}$ & $82.15 \pm 0.33^{\mathrm{b}}$ & $88.3 \pm 0.41^{\mathrm{d}}$ \\
\hline Yield $(\%)$ & $87.9 \pm 0.66^{\mathrm{d}}$ & $55.01 \pm 0.55^{\mathrm{b}}$ & $68.56 \pm 0.44^{\mathrm{d}}$ & $63.5 \pm 0.29^{\mathrm{b}}$ \\
\hline Colour difference $(\Delta \mathrm{E})$ & $8.41 \pm 0.03^{\mathrm{c}}$ & $16.52 \pm 0.23^{\mathrm{d}}$ & $27.34 \pm 0.59^{\mathrm{a}}$ & $18.37 \pm 0.03^{\mathrm{c}}$ \\
\hline
\end{tabular}

Control Sample: Enzymatically extracted juice before spray drying; MD: Maltodextrin; SD: Spray dried; GA: Gum Arabic. Data represented as mean \pm standard deviation, sample size $=3$. Values in the same column, followed by superscripted letters (a-d) are significantly different $(p \leq 0.05)$ as determined by DUNCAN Test. 


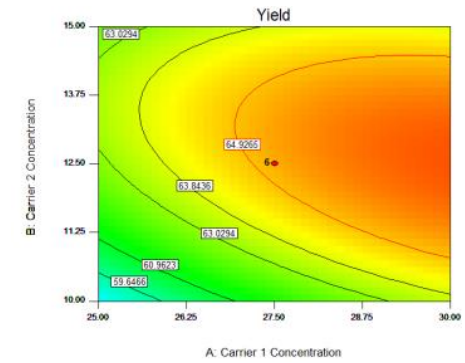

A
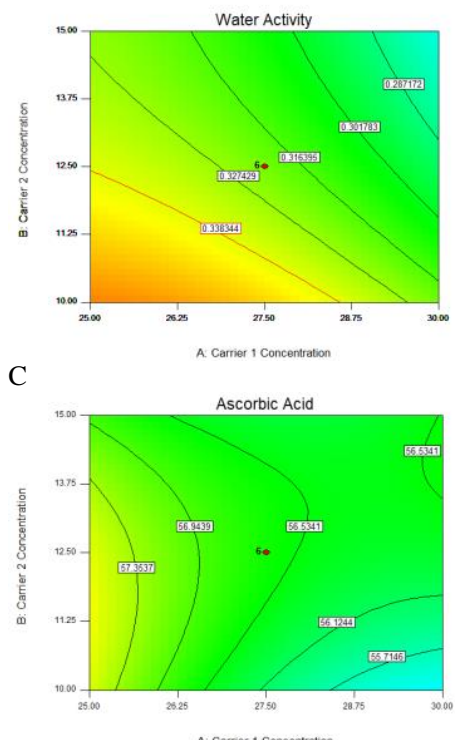

E

Figure 4 Response surfaces of Combined aided spray drying representing effect of Additive Concentration and Inlet Temperature on (a) Powder Yield (b) Moisture Content (c) Water activity (d) Solubility Time (e) Ascorbic Acid Content (f) Colour Change

\section{Colour of the reconstituted juice}

The linear terms of combined additives showed a significant $(p<0.001)$ effect on the colour difference of the reconstituted palm juice. The interaction terms of maltodextrin-gum Arabic $(p<0.01)$ and the quadratic terms of these additives $(p<0.05)$ had significant effects on the colour difference of reconstituted juice. Fig. 4(f) shows the response surfaces of colour difference. The presence of these additives increases the colour difference of the reconstituted juices from the extracted palm juice. These additives impart their colour to the final palm powder and the reconstituted juice. Similar results have been reported for spray-dried pineapple powder and cactus pear (Rodríguez-Hernández et al., 2005; Gabas $\boldsymbol{e}$ al., 2007). The colour difference data fits the equation extremely well with the highest $\mathrm{R}^{2}$, Adj. $\mathrm{R}^{2}$ and Predicted $\mathrm{R}^{2}$ (Table $2 \mathrm{c}$ ). The optimum value of the colour difference $(\Delta \mathrm{E})$ with combined additives was $18.37 \pm 0.03$. Other physicochemical properties of the reconstituted juice (Table 3 ) were similar to the enzymatically extracted palm juice.

Under optimized condition, the spray-dried palm powder with combined additives had a moisture content of $3.3 \pm 0.61 \%$ (db), ascorbic acid content of $54 \pm 0.0003 \mu \mathrm{g}$ of $\mathrm{AA} / \mathrm{ml}$, water activity of $0.29 \pm 0.05$, and solubility time of $31.6 \pm 0.33$ seconds. The Palm powder (Fig. 5) obtained was less hygroscopic and had better solubility in water.

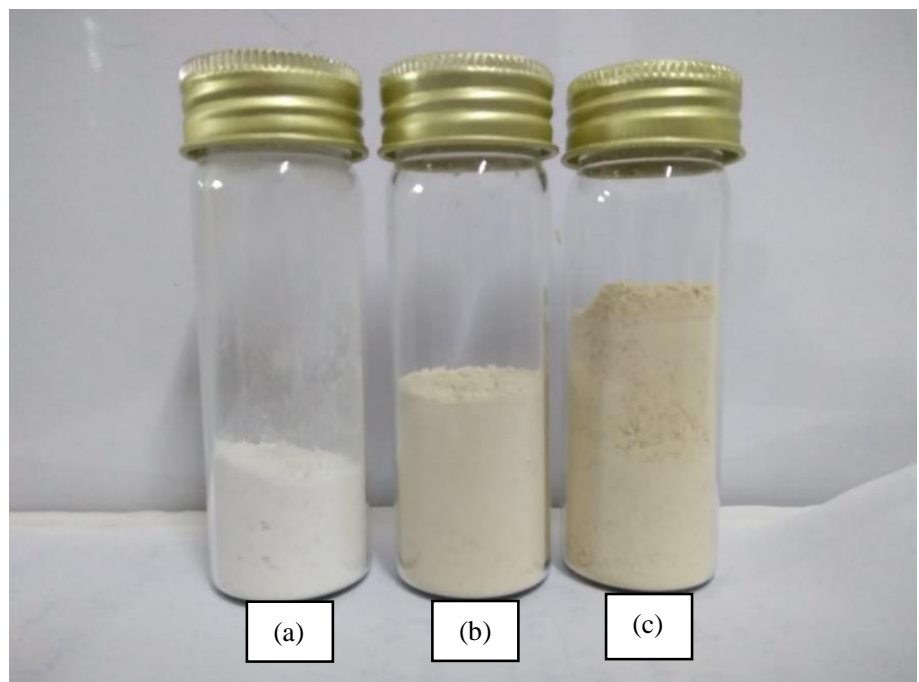

Figure 5 Palm Powder obtained from different Spray drying conditions (a) Maltodextrin aided spray-dried palm powder (b) Gum Arabic aided spray-dried palm powder (c) Combined Additive aided spray-dried palm powder

\section{CONCLUSION}

Palm (Borassus flabellifer) is a seasonal fruit rich in nutrients and antioxidants As extraction of palm pulp and juice is difficult, preservation and value-addition have not been taken up commercially. Palm juice was enzymatically extracted for this work. Again due to the high sugar content of the juice, shelf life is very less. Palm fruit powder could be a suitable alternative. In this work, spray-drying of the juice with multiple additives such as maltodextrin and gum Arabic, in combination, was explored. The additive concentration and inlet temperature of spray-drying were optimized for quality parameters of the powder and reconstituted juice using the central composite design of the response surface method. Spray-drying of enzymatically extracted palm juice was optimized at an inlet temperature of $140^{\circ} \mathrm{C}$ and with a combination of additives (maltodextrin and gum Arabic) at a ratio of 3:1. Palm powder obtained from these optimized spraydrying parameters had better yield, quality, and stability. Palm powder with gum Arabic had better quality than that with maltodextrin under optimum operating conditions. However, the palm powder with combined maltodextrin and gum Arabic had the best quality as compared to individual additive. The optimized palm powder had a moisture content of $3.3 \pm 0.61 \%(\mathrm{db})$, ascorbic acid content of $54 \pm 0.0003 \mu \mathrm{g}$ of $\mathrm{AA} / \mathrm{ml}$, water activity of $0.29 \pm 0.05$, and solubility time of $31.6 \pm 0.33$ seconds. The reconstituted palm juice had similar physicochemical properties as those with enzymatically extracted palm juice. These optimized parameters for spray drying of palm juice can be adopted in the industrial scale for making palm powder.

\section{REFERENCE}

Angel, R. C. M., Espinosa-Muñoz, L. C., Aviles-Aviles, C., González-García, R. Moscosa-Santillán, M., Grajales-Lagunes, A., \& Abud-Archila, M. (2009). Spray-drying of passion fruit juice using lactose-maltodextrin blends as the support material. Brazilian archives biology technology, 52(4), 1011-1018 http://dx.doi.org/10.1590/S151689132009000400026

Arunachalam, K., Saravanan, S., \& Parimelazhagan, T. (2011). Nutritional analysis and antioxidant activity of palmyrah (Borassus flabellifer L.) seed embryo for potential use as food source. Food science and biotechnology, 20(1), 143-149. https://doi.org/10.1007/s10068-011-0020-y

Bazaria, B., \& Kumar, P. (2018). Optimization of spray drying parameters for beetroot juice powder using response surface methodology (RSM). Journal of Saudi society agricultural sciences, 17(4), 408-415. https://doi.org/10.1016/j.jssas.2016.09.007

Chaurasiya, A. K., Chakraborty, I., \& Saha, J. 2014. Value addition of Palmyra palm and studies on the storage life. Journal of Food science technology, 51(4), 768-773.https://doi.org/10.1007/s13197-011-0561-3

Chegini, G. R., \& Ghobadian, B. (2007). Spray dryer parameters for fruit juice drying. World Journal of agricultural science, 3(2), 230-236.

Cynthia, S. J., Bosco, J. D., \& Bhol, S. (2015). Physical and structural properties of spray dried tamarind (Tamarindus indica L.) pulp extract powder with encapsulating hydrocolloids. International Journal of Food Properties, 18(8), 1793-1800. https://doi.org/10.1080/10942912.2014.940536

Fazaeli, M., Emam-Djomeh, Z., Ashtari, A. K., \& Omid, M. (2012). Effect of spray drying conditions and feed composition on the physical properties of black mulberry juice powder. Food Bioproducts Processing, 90(4), 667675.https://doi.org/10.1016/j.fbp.2012.04.006

Gabas, A. L., Telis, V. R. N., Sobral, P. J. A., \& Telis-Romero, J. (2007). Effect of maltodextrin and arabic gum in water vapor sorption thermodynamic 
properties of vacuum dried pineapple pulp powder. Journal of Food Engineering, 82(2), 246-252.

Gharsallaoui, A., Roudaut, G., Chambin, O., Voilley, A., \& Saurel, R. (2007) Applications of spray-drying in microencapsulation of food ingredients: An overview. Food Research International, 40(9), 1107-1121. https://doi.org/10.1016/j.jfoodeng.2007.02.029

Goula, A. M., \& Adamopoulos, K. G. (2010). A new technique for spray drying orange juice concentrate. Innovative Food Science \& Emerging Technology, 11(2), 342-351. https://doi.org/10.1016/j.ifset.2009.12.001

Horwitz, W. (2000). Official methods of analysis of AOAC International Vol. 1. AOAC International, Gaithersburg, MD, USA.

Ioana, V. S., Marieta, L., \& Vasile, L. (2015). The effect of enzymatic treatment on bioactive compounds and antioxidant capacity of pasteurized apple juice. Analele Universității din Oradea, Fascicula: Protecția Mediului, 25, 127 132.

Jittanit, W., Niti-Att, S., \& Techanuntachaikul, O. (2010). Study of spray drying of pineapple juice using maltodextrin as an additive. Chiang Mai Journal of Science, 37(3), 498-506.

Krishnaiah, D., Nithyanandam, R., \& Sarbatly, R. (2014). A critical review on the spray drying of fruit extract: Effect of additives on physicochemica properties. Critical reviews in food science nutrition, 54(4), 449-473. https://doi.org/10.1080/10408398.2011.587038

Largo Avila, E., Cortes Rodríguez, M., Velásquez, C., \& José, H. (2015) Influence of maltodextrin and spray drying process conditions on sugarcane juice powder quality. Revista Facultad Nacional de Agronomía Medellín, 68(1), 75097520. http://dx.doi.org/10.15446/rfnam.v68n1.47839

Lee, W. C., Yusof, S., Hamid, N. S. A., \& Baharin, B. S. (2006). Optimizing conditions for enzymatic clarification of banana juice using response surface methodology (RSM). Journal of food Engineering, 73(1), 55-63. https://doi.org/10.1016/i.jfoodeng.2005.01.005

Mohanty, S., Mishra, S., \& Pradhan, R. C. (2018). Optimisation of enzymatic extraction and characterization of palm (Borassus flabellifer) juice. Journal of Food Measurement and Characterization, 12(4), 2644-2656. https://doi.org/10.1007/s11694-018-9882-5

Muzaffar, K., \& Kumar, P. (2015). Parameter optimization for spray drying of tamarind pulp using response surface methodology. Powder Technology. 279, 179-184. https://doi.org/10.1016/j.powtec.2015.04.010

Muzaffar, K., Nayik, G. A., \& Kumar, P. (2018). Production of Fruit Juice Powders by Spray Drying Technology. International Journal of Advance Research. Science and Engineering. 7(3), 59-67.

Nishad, Jyoti \& Mir, Shabir \& Walia, Kanika. (2019). Optimization of Spray Drying Technology for Sugarcane Juice Using Natural and Synthetic Encapsulating Agents. Sugar Technology. 1-7.https://doi.org/10.1007/s12355018-0696-x

Ogbonna, A.C, Izuchukwu Abuajah, C., \& Eyo Ekpe, G. (2013). A comparative study of the nutritive factors and sensory acceptance of juices from selected Nigerian fruits. Hrvatski časopis za prehrambenu tehnologiju, biotehnologiju $i$ nutricionizam, 8(1-2), 47-51.

Phisut, N. (2012). Spray drying technique of fruit juice powder: some factors influencing the properties of product. International Food Research Journal. 19(4), 1297-1306.

Quek, S. Y., Chok, N. K., \& Swedlund, P. (2007). The physicochemical properties of spray-dried watermelon powders. Chemical Engineering and Processing: $\quad$ Process Intensification, 46(5), 386-392. https://doi.org/10.1016/j.cep.2006.06.020

Rodríguez-Hernández, G. R., Gonzalez-Garcia, R., Grajales-Lagunes, A., RuizCabrera, M. A., \& Abud-Archila, M. (2005). Spray-drying of cactus pear juice (Opuntia streptacantha): effect on the physicochemical properties of powder and reconstituted product. Drying. Technology, 23(4), 955-973.

Rout, P., \& Basak, U. C. (2014). Evaluation of antinutritional factors in sixteen wild edible fruits of Odisha, India. International Journal of Current Science, 13 34-42.

Sagu, S. T., Nso, E. J., Karmakar, S., \& De, S. (2014). Optimisation of low temperature extraction of banana juice using commercial pectinase. Food Chemistry, 151, 182-190. https://doi.org/10.1016/j.foodchem.2013.11.031

Shishir, M. R. I., \& Chen, W. (2017). Trends of spray drying: A critical review on drying of fruit and vegetable juices. Trends in Food Science \& Technology, 65, 49-67.

Shishir, M. R. I., Taip, F. S., Aziz, N. A., Talib, R. A., \& Sarker, M. S. H. (2016) Optimization of spray drying parameters for pink guava powder using RSM Food Science and Biotechnology, 25(2), 461-468 https://doi.org/10.1016/j.tifs.2017.05.006

Singh, A., Kumar, S., \& Sharma, H. K. (2012). Effect of enzymatic hydrolysis on the juice yield from bael fruit (Aegle marmelos Correa) pulp. American Journa of Food Technology, 7(2), 62-72.

Vijayakumari, V. P., \& Kiranmayi, P. (2014). Physicochemical and Functional Characteristics of Powder Prepared from Palmyra Fruit Pulp (Borassus flabellifer L.). International Journal of Current Microbiology and Applied Sciences, 3(09), 352
Vivek, K., Mishra, S., \& Pradhan, R. C. (2018). Physicochemical characterization and mass modelling of Sohiong (Prunus nepalensis L.) fruit. Journal of Food Measurement and Characterization, 12(2), 923-936. https://doi.org/10.1007/s11694-017-9708-x

Vivek, K., Mishra, S., \& Pradhan, R. C. (2019). Optimization of ultrasoundassisted enzymatic extraction of Sohiong (Prunus nepalensis) juice. Journal of Food Process Engineering, 42(1), e12948. https://doi.org/10.1111/ifpe.12948

Vivek, K., Mishra, S., \& Pradhan, R. C. (2020). Characterization of spray dried probiotic Sohiong fruit powder with Lactobacillus plantarum. LWT-Food Science and Technology, 117, 108699. https://doi.org/10.1016/j.lwt.2019.108699 Vivek, K., Mishra, S., \& Pradhan, R. C. (2021).Optimization of spray drying conditions for developing non-dairy based probiotic Sohiong fruit powder. International Journal of Fruit https://doi.org/10.1080/15538362.2020.1864567

Yousefi, S., Emam-Djomeh, Z., \& Mousavi, S. M. (2011). Effect of carrier type and spray drying on the physicochemical properties of powdered and reconstituted pomegranate juice (Punica Granatum L.). Journal of Food Science and Technology, 48(6), 677-684. https://doi.org/10.1007/s13197-010-0195-x 